\title{
Theorising the Concept of Product Branding: A Qualitative Approach to the History of Branding; the Case of the Nigerian Milk Industry
}

\author{
Aloy Okafor $^{1} \&$ Olusoji George ${ }^{2}$ \\ ${ }^{1}$ Leeds Business School, Leeds Beckett University, Leeds, United Kingdom \\ ${ }^{2}$ Faculty of Business Administration, University of Lagos, Lagos, Nigeria \\ Correspondence: Aloy Okafor, Leeds Business School, Leeds Beckett University, Leeds, United Kingdom. \\ E-mail: aloy.aloy@yahoo.com or golusoji@unilag.edu.ng
}

Received: January 31, 2016 Accepted: February 20, 2016 Online Published: March 25, 2016

doi:10.5539/ijms.v8n2p84

URL: http://dx.doi.org/10.5539/ijms.v8n2p84

\begin{abstract}
Product Branding is the process of inculcating unique values to a product in order to differentiate it from competing products. Components that differentiate products include: Name, Logo, Intellect, Culture and Values. This paper examines some western theorised Product Branding components and presents the understanding of these components from a Nigerian perspective. Social theory was used for the review of literature on Product Branding components, and in exploring the components' systemic relationships that promised values to stakeholders. Content Analysis was employed in examining the theories of Branding and the extent to which it could be applied in the Nigerian Milk industry. This study reveals that a brand's success largely depends on the extent of artistic selection of Product Branding components and the extent to which those components' interaction produces values for stakeholders. The study concludes that Brand Name, Brand Logo, Brand Intellect, and Brand Culture are components that exude values to milk brands in Nigeria.
\end{abstract}

Keywords: product branding, brand name, brand logo, brand intellect, brand culture, brand value, and milk in Nigeria.

\section{Introduction}

Keller \& Lehman (2006) state that Branding has emerged as a top management priority from 1996 to 2006 due to the growing realisation that brand is one of the most valuable intangible assets. The above assertion may be regarded as an understatement when critically evaluated against the trend of branding chronology (Copeland, 1923; de Chernatony, 2006).

For instance, literature affirms that branding caught the attention of scholars about ninety years ago; firstly from the work of Copeland (1923). Later, branding has consistently engaged the attention of academics and practitioners as could be seen in the works of: Jenkins \& Corbin (1938), Guest (1942), Lipstein (1959), Sheth (1968), Jacoby \& Chestnut (1978), Gupta (1988), Aaker (1991), de Chernatony (2006) and Kapferer (2012), among others. Definition of branding changes over time. Scholars assert that there exist about 200 different definitions of brand in literature (Candan, Unal, \& Ercis, 2013; Mise, Nair, Odera, \& Ogutu, 2013). The high recorded numerical definitions of branding as stated above are perhaps necessitated by different meanings that are attributable to branding. These may include descriptions of Product Branding as revealed in Aaker (1991); de Chernatony (2006), and Kapferer (2012); Company Branding as seen in Balmer (2005), Jones, Temperley, \& Lima (2009); City Branding as explored in Zenker \& Beckermann (2013) and Halachmi \& Meng (2013); and Country Branding as examined in Shahid, Shafique, \& Shokat (2012); among others.

This study does not intend to belabour comparing, contrasting or reconciling variants definitions of branding in other fields. The study's literature search is programmed to sieve only those definitions/descriptions that could uphold clarity of thoughts towards the achievement of the research over-all purpose.

Milk companies in Nigeria have the choice to develop a customised model of branding that would best suit their product, or choose from a number of Branding Models available in literature such as Aaker's (1996) Brand Equity Model and de Chernatony's (2006) Branding Iceberg Model, among others. In the case of adopting a model from the literature, milk companies must necessarily consider the impact of their operating environment on the model they intend to adopt. Hence, this study's objective is to determine the branding model that could be 
used for milk branding in Nigeria.

\section{The Conceptual Background}

Some definitions of branding are seen to largely concentrate on external features that distinguish a firm's product from competitors', for others a consistent internal promised level of quality to customers (Wood, 2000) and yet for others a combination of external features of product's distinctiveness and imbedded voice of promise. For a example: American Marketing Association (AMA) (1960) defines brand as a name, term, sign, symbol, or design, or a combination of them, intend to identify the goods and services of one seller or group of sellers and to differentiate them from those of competitor. Proponents of AMA's (1960) definition include; Kotler, Adam, Brown \& Armstrong (2001). This definition is, however, obviously replicated as a trademark definition by Miaoulis \& D'Amato (1978).

This apparently suggests that AMA's definition focuses only on external features of a brand. Again, a critical study of litigation documentaries by McJohn (2013) would unequivocally agree that American Marketing Association (1960)'s definition is an addendum of trademark. Trademark, includes signs like: "animated cow" of Cowbell Milk, a product of Promasidor Nigeria Ltd, and "image of boat sailors" of Peak Milk, a product of FreislandCampina WAMCO PLC. Although, Kumar, \& Srivastava (2013) state that the legal term for brand is trademark. However, a description that combines trademark with recognisable internal or intangible features of a brand may be more graspable. Hence, other definitions, contributions, arguments, and viewpoints that combine both tangible and intangible brand elements are examined below:

According to Aaker (1991), a brand is an asset for differentiating promises that link a product to its customers. Holt $(2002,2004)$ perceives branding as a functional means of differentiating products or services, increasing product recognition and reputation, thereby securing or gaining market share. Brands of products that have attained a high level customer confidence (Haghighi, Moetamedzadeh, \& Afrasiabi, 2013) close communication gaps between the manufacturer and customer (Kapferer, 2012), and also build customer loyalty. Branding provides an opportunity for organisations to enjoy high brand loyalty, name awareness, perceived quality and strong brand association with customers (Che-Ha \& Hashim, 2007). That being the case would mean that branding has become the major determinant of corporate vision realisation, and a tendentious influence on customers' dispositions.

Branding places greater emphasis on elaborating a distinctive, symbolic meaning or personality that differentiates a product from its rivals (Aaker, 1996; de Chernatony, 2006). Over time, brand concept has ranged from the brand acting as a simple identification device (American Marketing Association, 1960) to the development of complex, value-laden identities (Kapferer, 2012). The goals consumers have for a brand are numerous (Gordon, 2004). They include communication of particular aspects of self and lifestyle through the use of specific brands (Pandey \& Pandey, 2012).

The functions of branding may be categorised into three (Wheeler, 2009): Firstly, brand functions as navigation, helping consumers to choose from an array of choices (Aaker, 1996). Secondly, it provides the consumers with a reassurance of making the right choice (Keller, 1993). Thirdly, branding engages the use of distinctive imagery, language and associations to encourage customers to identify with the brand (Biljon \& Rensburgh, 2011).

de Chernatony's (2006) "Brand Triangle" shows that a consumer's brand search process starts from considering the brand's functional values (querying the brand content), its emotional values (how does these content fit his/her person), and finally its promised experience (what to benefit). In other words, there is a process of developing cognitive and affective disposition towards the brand. Wheeler (2009) asserts that the tool of branding may have changed but the fundamentals have not. Ubiquitously, the classical branding tools originate from, and are often designed by sellers of products to appease buyers of products. The next subsection presents the brief history of the Nigerian Milk Industry.

\subsection{Brief History of the Nigerian Milk Industry}

In recent times, the term milk is also used to refer to white coloured non-animal beverage such as Soya milk, Coconut milk, Almond milk and Rice milk (Dupont, Chouraqui, de Boissieu, Bocquet, Bresson, Briend, Darmaun, Frelut, Ghisolfi, Girardet, Goulet, Hankard, Rieu, Vidaihet, \& Turck, 2011). However, this study's interest lies in a white liquid that is produced by mammary glands of mammals, as defined in Black, Williams, Jones, \& Goulding (2002). Therefore, this study focuses on milk extracted from cow udder. Milk is either consumed as a necessary source of nutrition for young mammals before they are able to digest other types of food (Takeuchi, Wada, Kawasaki, Krejci, Noji, Kawada, Nakade, \& Harada, 2014). For some adult human beings, milk is consumed for its nutritional benefits to health or as an addiction that must be necessarily 
consumed at intervals.

Milk may be consumed in its original liquid form without any form of purification or preservation. Milk can be purified and/or preserved in the form of powder. According to Walshe, Grindle, Nell, \& Bachman (1991), milk is the most nutritious food known to man. Throughout the world, milk was said to be directly or indirectly consumed by about six billion people (FAO, 2010). Nutritional components of milk include Energy, Protein, Vitamins and Calcium.

The history of milk as a commercially viable product in Nigeria could be traced to the 1920s (Walker, 1981). According to Olaloku (1976), the various activities of the Nigerian Dairy Industry, which include: milk production, importation, processing, marketing, and consumption have been ongoing in Nigeria for over sixty years. However, the researchers in the course of this study have observed a scanty, and at times an outright unavailability of statistical data of milk production and consumption in Nigeria. This suggests an inadequate record of milk production by the milk manufacturers and a need for the Federal Bureau of Statistics to make more effort in documentation of milk production/consumption in the country.

Industrialised milk production in Nigeria is highly competitive. The industry is dominated by multinational companies that include; Promasidor Nigeria Ltd, FreislandCampina WAMCO PLC, Kneipe Nigeria Ltd, Chellarams PLC, Givanas Nigeria Ltd, and Chi Ltd.

Milk shelves in both organised retail shops such as Shoprite and unorganised open markets such as Idumota market showcase milk brands that are competing for loyalty of the Nigerian milk consumers. Milk brands that are usually on display on the shop counters are "animated cow" of Cowbell Milk, a product of Promasidor Nigeria Ltd; "image of boat sailors" of Peak Milk, a product of FreislandCampina WAMCO PLC; "animated happy sporting cow" of Dano milk, a product of Kneipe Nigeria Ltd; "a glass of white liquid milk" of Real Milk, a product of Chellarams PLC; "a cup of yellow coloured milk" of Luna Milk, a product of Givanas Nigeria Ltd; and "a glass of milk", of Loya Milk, a product of Promasidor Nigeria Ltd.

In 2007, a study conducted by Adetunji, Raufu, \& Olaniyi (2007) finds Peak Milk as the most consumed milk in Lagos, Nigeria, while a later study by Yekinni, (2013) reveals Cowbell Milk brand as the most consumed milk in Lagos, Nigeria. Peak Milk brand and Cowbell Milk brand are the most conspicuous milk brands in Nigeria with the highest Dairy market share in Nigeria. From the above, it could be inferred that the two companies are in the same strategic group as stated by Kuye (2009), hence, the existence of possible competition. What influences customers' loyalty to a particular brand, despite similarities in both products' offering is product branding. The next heading examines the concept of Product Branding.

\subsection{Product Branding}

Ham (2010) has examined Product Branding as product's Name: The customer recognises the product by its distinctive appellation represented on the label. However, Teixeira \& Deliza (2006) views product branding as Colour. The customer is signaled by identifying with the brand through the use of repetitious colour scheme. Reseachers have found a positive relationship between colour and choice preference (Badkoobehi, Elahi, \& Makui, 2011). The studies done by Raza \& Rehman (2012); Jabbar \& Baldwin (2010) reveal that perceptions can be influenced by the association of brand with images of the product. According to Glynn \& Chen (2009); perception of a product's quality is one of the most important elements for a brand and quality can be combined with prompts.

- Value is the true worth of a product over its closest substitute (Valls, Adrade, \& Arribas, 2011). Although the term "Value" is relative, and its definition is subjective, and highly dependent on individuals or the field of study. Operational definition of "Value" for this study aligns with Valls et al. (2011).

- Rivalry position compares the company's product with other companies' products by creating an element of competition (Rutihinda, 2008).

- Emotional is the need or desire to connect the product with the customer through a strong feeling that has a lasting impression on the memory (Debenham, Bridson, \& Vocino, 2007).

- Recognition Familiarity and integrity become interwoven with the brand (Mantonakis, 2011) through its external features, such as the brand name and logo.

Success of a brand depends on the extent to which the brand's Manager evaluates and re-evaluates the effectiveness of these properties in winning customers' loyalty for the brand (Wheeler, 2009). The measurement of effectiveness of each property is the extent to which it contributes in growing loyal customer base for the brand. To Wheeler (2009), branding is a disciplined process used to build awareness and extend customers' 
loyalty. The description of Product Brand as presented above is a picture of the concept from one standpoint.

Looking at Product Branding from another angle reveals how writers argue that brand could be described from four different perspectives: as a product (Chernev, 2003); as an organisation (Carrillo, Danowski, Castillo, \& Jimenez, 2011); as a person (de Chernatony, 2006); and as a symbol (Aaker, 1996). Broadly, description of Brand from this perspective is encapsulated in Aaker (1996) as a timeless Brand Identity.

Although, de Chernatony's (2006) description of Brand Identity differs significantly from Aaker (1996), de Chernatony (2006) states that Brand Identity are: brand positioning, brand presentation, brand personality, brand vision, brand relationship and culture. The next subtopic explores theoretical background of this study using social theory.

\section{The Theoretical Background}

The researchers, for the interest of this study elect to rely more on the version of Brand Identity by Aaker (1996). This is because of the generic nature of Aaker's components which (in the researchers' view) tends to subsume the identity components as presented in de Chernatony (2006). Therefore, Aaker (1996) Brand Identity is briefly, but critically evaluated as follows:

\subsection{Aaker's (1996) Model of Branding}

\subsubsection{Brand as a Product}

A product is a bundle of benefits (Blythe, 2008) that is offered to a market for acquisition or consumption by customers in order to satisfy a want or need (Armstrong \& Kotler, 2008). The attribute of satisfaction of a given product can provide functional benefits and sometimes emotional benefits for customers (Oliver, 1997). A product's benefits as presented in Oliver (1997) are mostly described as values for the customers (Aaker, 1991) and values for the firms (Schein, 1984; Aaker, 1991). A firm's desire to continue in business is possible with the availability of its viable product in the marketplace, without which there will be a high probability that the firm will collapse. Therefore, a firm without a product can be likened to a human body without a heart (lifeless).

Ambler (1992) takes a consumer-oriented approach in defining a product brand as the promise of the bundles of attributes that a consumer buys and it provides satisfaction. Again this definition is seen to be related to that of Blythe (2008), and Armstrong \& Kotler (2008). The attributes that make up a product brand may be real or illusory, rational or emotional, tangible or invisible (Kumar \& Srivastava, 2013). Products are becoming so similar that customers seem to be having difficulty in differentiating one from another, in which case brands becomes the only helper that customers can rely on in making choices by delineating the unique qualities and value that each product promises (Van Auken, 2003).

This view has long been supported by (Park \& Srinivasan, 1994 ) arguing that brand assists customers to make purchase decisions in increasingly clustered retail environments, providing useful clue as to a product's quality, attributes and personality (de Chernatony, 2006). The goal of linking a brand with a product class is not to gain recall of the product when a brand is mentioned (Aaker, 1996), but rather it is more important for customers to remember the brand when the need for the product arises. The above description of a brand aligns with the views of Pitta \& Katsanis (1995) that without a product there may be no brand.

\subsubsection{Brand as an Organisation}

Researchers have argued that customers' likeness for a company can influence his or her choice of the product of that company (Javalgi \& Moberg, 1997; Da Silva \& Alwi, 2006). It becomes necessary to evaluate the extent to which brand can be ascribed to a company.

Branding an organisation is a function of continuous innovation, drive for quality and concern for the environment (Tu, Wang, \& Chang, 2012) with the aim of building for approval of stakeholders. This means that an organisation that is positively perceived by stakeholders (in this case; customers) may influence their choice of the company's products.Tu et al. (2012) found a strong positive relationship between corporate image, customer satisfaction and customer loyalty. This finding suggests that the image of the organisation is an important area to consider when branding a product.

Minkiewicz, Evans, Bridson, \& Mavondo (2008) provide further support for the notion of organisation as a product, by construing corporate image as consumers' combined perception of the product brand and what individuals know or believe about an organisation. In other words, corporate image is described as stakeholders' beliefs, perceptions, feelings and attitudes towards an organisation (Davies, Chun, Da Silva, \& Roper, 2004). There is a connection between an individual's image of the organisation and that person's behaviour towards it (Balmer 1998). From the discussions, it seems compelling to accept an organisation as part and parcel of a 
product brand.

\subsubsection{Brand as a Person}

Like a person, a brand can be perceived as having a unique personality (Rositer \& Percy, 1996). Brand personality explains how the metaphor of a brand as a person facilitates the rapid appreciation of the brand's emotional values (Harris \& de Chernatony, 2001). The perspective of brand as person suggests a brand identity that is richer and more interesting than one based on product attributes (Aaker, 1996). When choosing between competing brands, customers assess the fit between the personalities of competing brands and the personality they want to project (Dowling \& Staelin, 1994), this may be inferred from design and packaging (Raza \& Rehman, 2012) along with other marketing controlled clues such as pricing (Biljon \& Rensburgh, 2011), and the type of store selling the brand (Bloemer \& Ruyter, 1997).

The above discussion suggests that consumers are loyal to the brand that relates to their personality. When the product brand personality equals the consumer's personality, then it becomes possible for a strong positive relationship to emerge between the brand and the customer.

\subsubsection{The Brand as Symbol}

Brand's symbolic meaning helps consumers understand and express aspects of themselves to others (McCracken, 1993). A strong symbol can provide cohesion and structure to identify and make it easier to gain recognition and recall. Definition of a brand by American Marketing Association (1960) suggests that symbol is a key ingredient of brand development, and its absence can be a substantial handicap (Biljon \& Rensburgh, 2011). If for instance there exist no symbolic features that uniquely demarcate one product from another, then the essence of branding a product would be meaningless (McJohn, 2013). The discussions and evaluations of Aaker's (1996) Brand Identity could be encapsulated in the description of de Chernatony's (2006) brand components.

\section{2 de Chernatony's (2006) Model of Branding}

de Chernatony (2006) suggests that the components of Branding are: Name, Logo, Intellect, Culture and Values. de Chernatony's (2006) Branding Icerberg Model is presented in Figure 1 below.

Overall definitions, descriptions and evaluations of Aaker (1996) "brand identity" as displayed above could be encapsulated in the description of de Chernatony (2006) "brand components"; stressing that a brand is: a name, logo, intellect, culture and values.

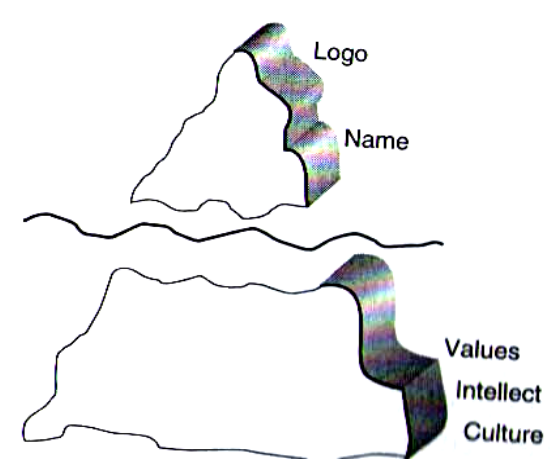

Figure 1. The branding iceberg

While the first half of a brand, example: name and logo (de Chernatony 2006) are categorised as the external features of a brand, in other words, visible to all stakeholders; example: trademark and design. The second half; example: intellect, culture and values are grouped as internal components, in other words, invisible to some stakeholders. It is a conscious combination of these components (visible and invisible) that may be referred as Product Branding (de Chernatony, 2006).

de Chernatony (2006)'s brand components, for the purpose of appropriate placement of the constructs for this study may be modified as shown in Figure 2 below: 


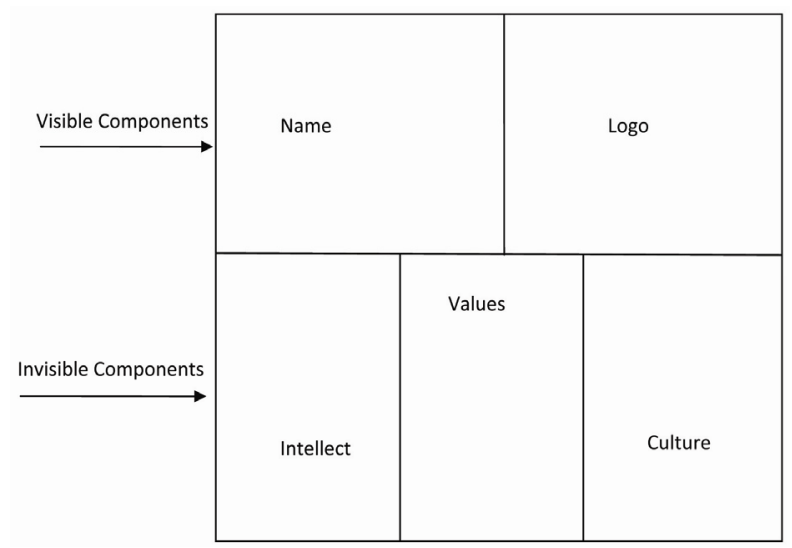

Figure 2. The branding components

Source: Branding components (adapted from de Chernatony, 2006).

The researchers briefly discuss what each component stands for:

\subsubsection{Brand as Name and Logo}

Brand Name and Brand Logo have been described as external features of branding (de Chernatony, 2006) and also a Legal instrument (McJohn, 2013) whose combination is often referred to as trademark (Kumar, 2013). Names and/or Logos are more often used to differentiate a firm's offering of guarantee of consistent level of quality (Wood, 2000), than other invisible features of a brand, such as: Intellect, Culture and Values.

One may opine that the external components of branding (Name and Logo) are perhaps the easiest and the most memorable distinctions between products. It is only after a name has been determined for the product, affixed and pronounced by the company that customers may start to question where else is the product different from others? A study conducted by Rio, Vazquez \& Iglesias (2001) finds that Spanish consumers are more attached to brand names than to core products.

In the United States, the name "Nike" (sports wears) is viewed as a symbol of quality more than the core products themselves. Brand Name (and Logo) contributes to brand awareness (Brucks, Zeithaml, \& Naylor, 2000) and a powerful legal instrument that deter imitators.

\subsubsection{Brand as Intellect}

These are inherent attributes of a brand that attract customers. Intellect according to Labuschagne (2010) may be considered from four facets: Aesthetics, Reasoning, Skillfulness and Social Intellect. Labuschagne's (2010) definitions of the facets may be summarised as the ability to understand the social environment through empathic skillful people who have the capacity of being resourceful in initiating business opportunities and/or the capacity of being resourceful to complete an existing task.

\subsubsection{Brand as Culture}

Culture is what blends the values that are embedded in a brand (Kumar, 2013). Although culture domiciles in the company and visibly operates mostly among human beings in the organisation, its intricacies follow the company's products down to the market place and influence choice of brands in the market. This may be seen in research studies that found a positive relationship between product origin and customer loyalty to a brand.

\subsubsection{Brand as Value}

Identifying values enables an organisation to know why it is different (de Chernatony, 2006). Brand Values are usually conceived from the process of the company directing resources to influence customers. Blythe (2008) has defined a product as a bundle of values; while Urde (2003) states that corporate brands must reflect organisational values. These assertions suggest that the overall interest and objective for branding a product is to inculcate unique values in it, such that can significantly differentiate it from competition and assure maximum benefit to stakeholders.

Aaker's (1996) components of a brand originate from the United States of America (the author's environment), while de Chernatony (2006) branding components have origin in the United Kingdom. The two scholars operate from a similar culture (Western culture) as documented in Szncycer, Takemura, Delton, Sato, Robertson, Cosmides, \& Tooby (2012) that is different from the culture in Nigeria (George, Kuye, \& Onokala, 2012). 
The next subsection examines Aaker's (1996) Brand Identity components with de Chernatony's (2006) branding Iceberg components in order to adopt or adapt a branding model that could be appropriate for use in the Nigerian Milk Industry.

\subsection{Linking Aaker's (1996) Branding Components with de Chernatony's (2006) Components of Branding}

The researchers' critical evaluation of Aaker's (1996) brand identity against de Chernatony's (2006) branding components suggests a strong association of the two variants. The researchers' further examination of the two works shows that the branding components of de Chernatony (2006) seem to supplant Aaker's (1996) components. The researchers' assessment is as modelled in Figure 3 below:

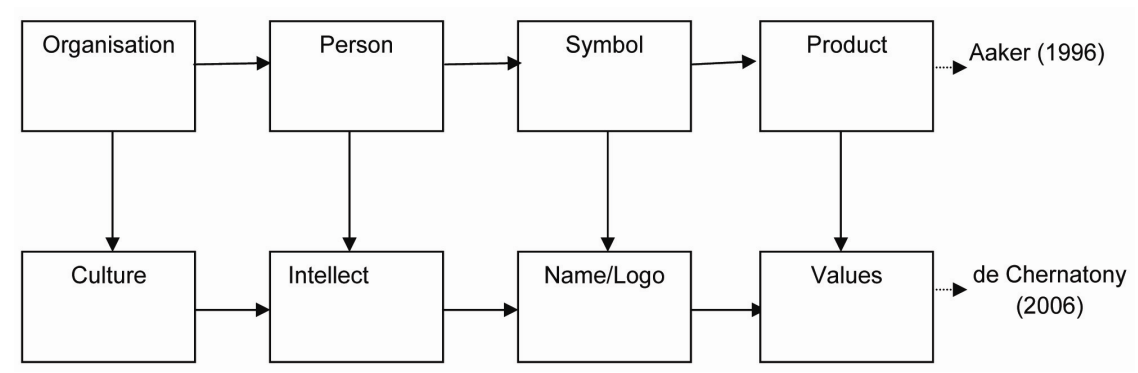

Figure 3. Linking Aaker's (1996) model with de Chernatony's (2006) model

Sorce: Adapted from Aaker (1996) and de Chernatony (2006).

The description of Symbol as presented in Aaker (1996) and as argued above may be referred to as Brand Name and Brand Logo. Brand's symbol of recognition is what differentiates a product from another (Aaker, 1996), while Brand Name and Brand Logo are described as the external features that differentiate products (de Chernatony, 2006). Brand Symbol and Brand Name/Logo are external characteristics that differentiate brands.

Aaker's (1996) idea of Brand as a Person conforms to the description of Brand as Intellect by de Chernatony (2006). Every normal person is assumed to possess a great intellectual prowess; if a brand is a Person according to Aaker (1996), then the Brand Person is an assumed intellect (de Chernatony, 2006). The description of Brand as an Organisation (Aaker, 1996) seems to be subsumed in the de Chernatony's (2006) definition of brand as a Culture. Culture is the substance that glues the divergent traits of people in an organisation. It is culture that unifies the productivities of organic functions of an organisation (McNamara, 2009) to produce a unique brand of product. When reasoned well, it appears clear that culture is the foundation of all organisational activities. Therefore, Aaker's (1996) Brand as an Organisation seems to align with de Chernatony's (2006) idea of Brand as Culture.

de Chernatony (2006) has presented Brand as a Value, the researchers argue that brand as a value represents the underlying essence of branding, and a float chamber for other branding components (Symbol or Name/Logo, Intellect or Person, Culture, and Product). One of the reasons for branding a product is to ensure that corporate objectives are achieved. It is therefore logical to assume that the whole essence of other brand-components should be to add value to the company's product. With this, brand value by de Chernatony (2006) and brand as a product by Aaker (1996) is inseparable.

As demonstrated above, Aaker's (1996) brand identity is argued in this study to be subsumed in de Chernatony's (2006) brand components. Going forward therefore, the researchers adapt de Chernatony (2006) branding components, with a slight modification. Hence, we define a brand as a bundle of values that emanates from culture, intellect, name and logo of a product.

The above section showcases the basic properties of a brand; it went further to compare western theorised branding components studies (Aaker, 1996; de Chernatony, 2006). In line with Social theory's tradition, the researchers adapt de Chernatony's (2006) brand components and modify it to reflect the study's operational definition of Product Branding as presented in Figure 4 below: 


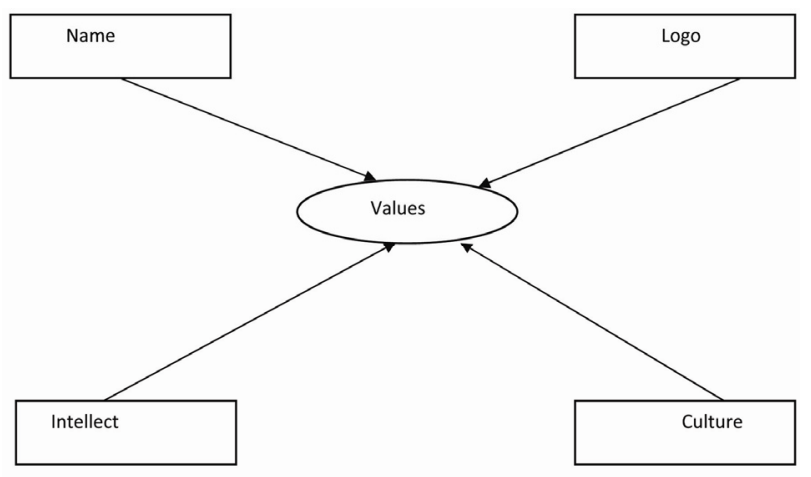

Figure 4. The product branding model

Source: Branding components adapted from de Chernatony (2006).

\section{Methodology}

The objective of this paper is to scrutinise some components of Product Branding (Aaker 1996; de Chernatony 2006). This study enquired in to these components relying on secondary data. Qualitative research of this kind provides detailed information that leads to a logical conclusion (Bryman \& Bell 2011). This study uses inductive approach that aims at developing a theory of Product Branding from the Nigerian perspective (Saunders, Lewis, \& Thornhill, 2009).

Bryman \& Burgess (2002) have showcased many researchers who have achieved excellence in qualitative method. Researchers from qualitative background have argue that qualitative studies should be judged or evaluated according to quite different criteria from those used by quantitative researchers (Lincoln \& Guba 1985).

The leading proponents of qualitative method (Lincoln \& Guba 1985; Teddlie \& Tashakkori, 2006) propose two primary criteria (Credibility and Trustworthiness), each of these has an equivalent criterion in quantitative research. According to Bhattacherjee (2012) credibility parallels validity; dependability parallels reliability; and conformability; parallels objectivity.

In this study, the researchers use content analysis in evaluating the applicability of theories of branding according to de Chernatony (2006) in the milk industry in Nigeria. The specific type of content analysis approach chosen by a researcher varies with the theoretical and substantive interests of the researcher and the problem being studied (Weber, 1990). The researchers critiqued the western conceived theory of branding and culture-fair it for use in the Nigerian Milk industry. Hseih \& Shannon (2014) state that content analysis is a flexible method for analysing text data, ranging from impressionistic, intuitive, and interpretive analyses to systematic, strict textual analyses. This study uses the theory of National Culture (Hofstede, 1991) in evaluating the application of de Chernatony's (2006) British theorised Branding components in the Nigeria Milk Industry.

\section{Discussion}

Existing theories of branding aim to ascertain a comprehensive components that companies may direct their marketing attention to; in order for their brand to compete favourably in the market place (Hampf \& Lindberg-Repo, 2011). Each theory of branding provides a line of credible argument that emphasises its importance in achieving customers' preference for a brand of product.

Many of these theories have been observed to be conceived in the Western Countries' environment, and yet delivered for application by anybody that cares irrespective of subculture's influences. Hence, a need for this descriptive study that aims at rationalising the underlying meanings and suggested applications of some of these theories in African perspective; as represented in the Nigerian context.

Globalization with respect to advancement in information technology may have contributed in wholesome application of Product Branding theory of de Chernatory (2006) in Nigeria. However, the acceptability of the components of the theory (Name, Logo, Intellect, Culture, and Values) may differ significantly between countries.

As discussed earlier, the invisible components of branding, such as intellect, and culture may be reasoned in terms of perceived competence of the brand's manufacturer or the brand's country of origin by people from different cultural background, the visible components; such as Name and Logo may be valued differently by 
prospects from different countries.

From the foregoing, the Nigerian milk industry may largely dwell on the theory of National culture in order to allow the infusion of Nigerian cultural context into their product branding strategies. Hofstede \& Hofstede (2005, p. 3) cited in George, Owoyemi, \& Onakala (2012) define National Culture as the "Software of the mind". The appreciation of values in each component is a function of the cultural background that shapes the evaluator's perception. What the name and logo of "Peak milk" or "Cowbell milk" represent to a Swiss or a Briton may be different from what it represents to a Nigerian.

\section{Conclusion}

This paper concludes that Brand Value component is dependent on Brand Name, Brand Logo, Brand Intellect, and Brand Culture. This study's findings differ significantly from de Chernatony's (2006) model which states that the components of branding are independent of each other. From the Nigerian perspective, Name, Logo Intellect, and Culture are the vital organs of branding that necessarily flow into brand's "Value chamber". It is that Brand Value component that influences the distinctive nature of the brand and its unique perception by stakeholders. Product branding department of a company is an important cost center whose success or failure responds in the going concern objective(s) of the products' oriented company. If the essence of branding is to achieve stakeholders' expectations, then branding components that do not fit into the social realities of a business' operating environments could damage the company sooner or later.

\section{References}

Aaker, D. A. (1991). Managing Brand Equity: Capitalizing on the Value of Brand Name. New York: Free Press.

Aaker, D. A. (1996). Measuring Brand Equity across Products and Markets. California Management Review, 38(3), 102-120. http://dx.doi.org/10.2307/41165845

Adetunji, M. O., Raufu, M. O., \& Olaniyi, A. O. (2007). Effect of Advertising and Sale Promotion on Demand for Diary Products in Lagos Metropolis, Nigeria. Social Sciences, 2(3), 336-339.

Ambler, T. (1992). Marketing's Third Paradigm. Business Strategy Review, 5(4).

American Marketing Association. (1960). Marketing Definitions: A Glossary of Marketing Terms. Chicago, IL: AMA.

Armstrong, G., \& Kotler, P. (2008). Marketing: An Introduction (9th ed.). Upper Saddle River, NJ: Printice Hall.

Badkoobehi, H., Elahi, B., \& Makui, A. (2011). Business Research Yearbook. Publication of The International Academy of Business Discipline.

Balmer, J. M. T. (2005). Corporate Brand Cultures and Communities. In J. E. Schroeder \& M. Salzer-Morling (Eds.), Brand Culture (pp. 34-49). London: Routledge.

Bhattacherjee, A. (2012). Social Science Research: Principles, Methods, and Practices. AnolBhattacherjee.

Biljon, W. V., \& Rensburgh, J. V. (2011). Branding and Packaging Design: Key Insights on Marketing Milk to Low-income Markets in South Africa. African Journal of Business Management, 5(22), 9548-9558.

Black, R. E., Williams, S. M., Jones, I. E., \& Goulding, A. (2002). Children Who Avoid Drinking Cow Milk Have Low Dietary Calcium Intakes and Poor Born Health. American Journal of Clinical Nutrition, 76(3), 675-680.

Bloemer. J., \& de Ruyter, K. (1997). Customer Loyalty in Extended Service Settings: The Interaction Between Satisfaction, Value Attainment and Positive Mood. International Journal of Bank Marketing, 16(7).

Blythe, J. (2008). Consumer Behaviour (1st ed.). London: Thompson.

Brucks, M., Zeithaml, V. A., \& Naylor, G. (2000). Price of Brand Name as Indicator of Quality Dimensions for Consumer Durables. Journal of Academy of Marketing Science, 28(3). http://dx.doi.org/10.1177/0092070300283005

Bryman, A., \& Bell, E. (2011). Business Research Methods (3rd ed.). New York, Oxford Press.

Bryman, A., \& Burgess, G. (2002). Analyzing Qualitative Data. London and New York: Routledge

Candan, B., Unal, S., \& Ercis, A. (2013). Analysing the Relationship between Consumption Values and Brand Loyalty of Young People: A Study on Personal Care Products. European Journal of Research on Education, Special Issue, 29-46. Retrieved from http://iassr.org/journal 
Carrillo, V., Danowski, J., Castillo, A., \& Jimenez J. L. T. (2011). Semantic Networks for Corporate Communication Concepts and Crisis. Differences Based on Corporate Reputational.

Che-Ha, N., \& Hashim, S. (2007). Brand Equity, Customer Satisfaction and Loyalty: Malaysian Banking Sector. International Review of Business Research Papers, 3(5), 123-133.

Chernev, A. (2003). Product Assortment and Individual Decision Process. Journal of Personality and Social Psychology, 85(1), 151-162. http://dx.doi.org/10.1037/0022-3514.85.1.151

Copeland, M. T. (1923). Relation of Consumers' Buying Habits to Marketing Methods. Harvard Business Review, 1(3), 282-289.

Da Silva. R. V., \& Alwi, S. F. S. (2006). Online Brand Attributes and Online Cooperate Brand Images. European Journal of Marketing, 42(9/10).

Davies, G., Chun, R., Da Silva, R., \& Roper, R. (2004). A Corporate Character Scale to Assess Employee and Customer Views of Organisation Reputation. Corporate Reputation Review, 7(2). http://dx.doi.org/10.1057/palgrave.crr.1540216

de Chernatony, L. (2006). From Brand Vision to Brand Evaluation: The Strategic Process of Growing and Strengthening Brands. Burlington: Elsevier Ltd.

Debenham, T., Bridson, K., \& Vocino, A. (2007). The Explanatory Potential of Congruence in the Relational Between Retail Image, Brand Image and Retail Customer Satisfaction. ANZMAC, 2007, 3Rs, Reputation Responsibility Relevance. University of Otago, School of Business, Dept. of Marketing, Dunedin, pp. 380-387.

Dowling, G. R. (1994). Corporate Reputations, Strategies for Developing the Corporate Brand. London: Kogan Page.

Dupont, C., Chouraqui, J. P., de Boissieu, D., Bocquet, A., Bresson, J. L., Briend, A., ... Turck, D. (2011). Dietary treatment of cows' milk protein allergy in childhood: a commentary by the Committee on Nutrition of the French Society of Paediatrics. British Journal of Nutrition, 107(3), 325-338. http://dx.doi.org/10.1017/S0007114511004831

FAO. (2010). Status of and Prospects for Smallholder Milk Production. A Global Perspective. Food and Agriculture Organisation.

Glynn, M. S., \& Chen, S. (2009). Consumer-Factors Moderating Private Label Brand Success: Further Empirical Result. International Journal of Retail and Distribution Management, 37(11), 896-914. http://dx.doi.org/10.1108/09590550910999343

Gordon, W. (2004). Consumer Decision-Making. Admap, 454(October).

Guest; L. P. (1942). The Genesis of Brand Awareness. Journal of Applied Psychology, 26, 800-808. http://dx.doi.org/10.1037/h0055390

Gupta, S. (1988). Impact of Sales Promotions on When, What, and How Much to Buy. Journal of Marketing Research, 25(November), 342-355. http://dx.doi.org/10.2307/3172945

Haghighi, M., Moetamedzedeh, H. R., \& Afrasrabi, N. (2013). Analysis and Application of Extended Classification System in Predicting the Effect of Brand Equity on Continuity and Promotion of Customer Relationship in Banking Industry. Global Journal of Science, Engineering and Technology, 6, 23-30.

Halachmi, A., \& Meng, H. (2013). City Branding and Citizen Participation: A Comparative Case Study of Xiamen (China) and Nashville (USA). Journal of US-China Public Administration, 10(1), 77-94.

Ham, T. (2010). Branding and Positioning to Satisfy the Customer's Appetite: An Educational Case Study. American Association of School Administrators. Journal of Scholarship and Practice, 7(2), 45-55.

Hampf, A., \& Lindberg-Roper, K. (2011). Branding: The Past, Present, and Future: A Study of the Evolution and Future of Branding. Hanken School of Economics, Department of Marketing. 00101 Helsinki, Finland.

Harris, F., \& de Chernatony, L. (2001). Corporate Branding and Corporate Brand Performance. European Journal of Marketing, 35(3), 4.

Hofstede, G. (1991). Cultures and Organisations: Software of the Mind. New York: McGraw-Hill

Hofstede, G., \& Hofstede, G. J. (2005). Cultures and Organizations, Software of the Mind: Intercultural Cooperation and Its Importance for Survival. London, New Delhi, New York: McGraw-Hill. 
Holt, D. (2002). Why Do Brands Cause Trouble? A Dialectical Theory of Consumer Culture and Branding. Journal of Consumer Research, 29, 70-90. http://dx.doi.org/10.1086/339922

Holt, D. (2004). How Brands Become Icons. Boston, MA: Harvard Business School Press.

Jabbar, Z., \& Baldwin, L. (2010). Developing Brand Personality Through Colour Construct-A Conceptual Investigation.

Jacoby, J., \& Chestnut, R. (1978). Brand Loyalty. Journal of Marketing Research, 56(1), 6-21.

Javalgi, R. G., \& Moberg, C. R. (1997). Service Loyalty: Implications for Service Providers. The Journal of Services Marketing, 11(3), 165-179. http://dx.doi.org/10.1108/08876049710168663

Jenkins, J. C., \& Corbin, H. H. (1938). Dependability of Psychological Brand Barometers. II. The problem of validity. Journal of Applied Psychology, 22(3), 252-260. http://dx.doi.org/10.1037/h0057255

Jones, B., Temperley, J., \& Lima, A. (2009). Corporate Reputation in the Era of Web 2.0. The Case of Primak. Journal of Marketing Management, 25(9), 297-939.

Kapferer, J. N. (2012). The New Strategic Brand Management: Advanced Insights and Strategic Thinking. London: Kogan Page.

Keller, K. L. (1993). Conceptualizing, Measuring, and Managing Customer-Based Brand Equity. Journal of Marketing, 57(January), 1-22. http://dx.doi.org/10.2307/1252054

Keller, K. L., \& Lehman, D. R. (2006). Brands and Branding: Research Findings and Future Priorities. Marketing Science, 25(6), 740-759. http://dx.doi.org/10.1287/mksc.1050.0153

Kotler, P., Adam, S., Brown, L., \& Armstrong, G. (2001). Marketing Segmentation, Targeting and Positioning. Principles of Marketing. Sidney: Prentice Hall.

Krefting, I. (1991). Rigor in Qualitative Research: The Assessment of Trustworthiness. The American Journal of Occupational Therapy. http://dx.doi.org/10.5014/ajot.45.3.214

Kumar, S. J., \& Srivastava, R. K. (2013). An Exploratory Study of Product and Brand Positioning Typologies with Respect to Pharmaceutical Companies. Review of Integrative Business and Economics Research, 2(2).

Kustini, N. I. (2011). Experiential Marketing, Emotional Branding, and Brand Trust and their Effect on Loyalty on Honda Motorcycle Product. Journal of Economics, Business and Accountancy, 14(1), 19-28. http://dx.doi.org/10.14414/jebav.v14i1.12

Kuye, O. L. (2009). Managing Process and Concepts. Lagos: Concept Publications.

Labuschagne, A. (2010). South African Personality Inventory: The Development of an Investigation into the Psychometric Properties of the Intellect Cluster. Dissertation submitted to North-West University (Potchefstroom Campus).

Lincoln, Y. S., \& Guba, E. A. (1985). Naturalistic Inquiry. Beverly Hills, CA: Sage.

Lipstein, B. (1959). The Dynamics of Brand Loyalty and Brand Switching. Proceedings, Fifth Annual Conference. Advertising Research Foundation.

Mantonakis, A. (2011). A Brief Pause between a Tagline and Brand Increases Brand Name Recognition and Preference. Applied Cognitive Psychology.

McCracken, G. (1993). The Value of the Brand: An Anthropological Perspective. In D. A. Aaker \& A. L. Biel (Eds.), Brand Equity and Advertising (pp. 125-142). Hillsdale, NJ: Lawrence Erlbaum Associates.

McJohn, S. (2013). Top Tens in 2012: Patent, Trademark, Copyright and Trade secret Cases Northwestern. Journal of Technology and Intellectual Property, 11(4).

Mialouis, G., \& Anato, N. (1978). Consumer Confusion and Trademark Infringement. Journal of Marketing, 42, 48-55. http://dx.doi.org/10.2307/1249885

Minkiewicz, J., Evans, J., Bridson, K., \& Mavondo, F. (2008). An investigation of Corporate Image, Customer Satisfaction and Loyalty. Australian and New Zealand Marketing Academy Conference, 2008, Marketing: Shifting the focus from Mainstream to Offbeat. Promaco Conventions, Canning Bridge, W.A., pp. 1-7.

Mise, J. K., Nair, C. Odera, O., \& Ogutu, M. (2013). Comparative Study on Brand Loyalty in Kenya and India Consumer of Softdrinks Market. Global Journal of Management and Business Research Marketing, 13(3).

Oliver, R. L. (1997). Satisfaction: A Behavioural Perspective on the Consumer. New York: Irwin/McGraw-Hill. 
Pandey, A. C., \& Pandey, M. K. (2012). Relationship between Lifestyle and Brand Preference-A Case of Television. International Conference on Technology and Business Management, March, 26-28.

Park, C. S., \& Srinivasan, V. (1994). A Survey-Based Method for Measuring and Understanding and Brand Equity and its Extendibility. Journal of Marketing Research, 31, 271-288. http://dx.doi.org/10.2307/3152199

Pitta, D. A., \& Katsanis, P. L. (1995). Understanding Brand Equity for Successful Brand Extension. Journal of Consumer Marketing, 12(4), 51-64. http://dx.doi.org/10.1108/07363769510095306

Raza, A., \& Rehman, Z. (2012). Impact of Relationship Marketing Tactics on Relationship Quality and Customer Loyalty: A Case Study of Telecom Sector of Pakistan. African Journal of Business Management, 6(14).

Rio, A. B., Vazquez, R., \& Iglesias, V. (2001). The Effects of Brand Associations on Consumer Response. Journal of Consumer Marketing, 18(5), 410-425. http://dx.doi.org/10.1108/07363760110398808

Rositer, J., \& Percy, L. (1996). Advertising Communications and Promotion Management. New York: McGraw-Hill.

Rutihinda, C. (2008). Factors Influencing The Internationalization of Small and medium Size Enterprises. International Business and Economics Research Journal, 17(12).

Saunders, M., Lewis, P., \& Thornhill, A. (2009). Research Method for Business Students. New York: Pearson Education Limited.

Schein, E. H. (1984). Coming to a New Awareness of Organisation Culture. Sloan Management Review.

Shahid, H., Shafique, O., \& Shokat, A. (2012). Nation Branding: Ghana. Developing Country Studies, 2(10).

Sheth, J. N., \& Venkatesan, M. (1968). Risk-Reduction Processes in Repetitive Consumer Behavior. Journal of Marketing Research, 5, 307-310. http://dx.doi.org/10.2307/3150350

Szncycer, D., Takemura, K., Delton, A. W., Sato, K., Robertson, T., Cosmides, L., \& Tooby, J. (2012). Cross-Cultural Difference and Similarities in Proneness to Shame: An Adaptationist and Ecological Approach. Evolutionary Psychology, 10(2), 352-370.

Takeuchi, H., Wada, K., Kawasaki, K., Krejci, M., Noji, T., Kawada, T., ... Harada, T. (2014). Effect of Cow Milk Intake at Breakfast on the Circabian Typology and Mental Health of Japanese Infants Aged 1-6 years. Psychology, 5(2), 172-176. http://dx.doi.org/10.4236/psych.2014.52027

Teddlie, C., \& Tashakkori, A. (2006). A General Typology of Research Designs Featuring Mixed Methods. Research in the School, 13(1), 12-28.

Teixera, E., \& Deliza, R. (2006). Consumer Research: Extrinsic Variables in Food Studies. British Food Journal, 108(11).

Tu, Y., Wang, C., \& Chang, H. (2012). Corporate Brand Image and Customer Satisfaction on Loyalty: An Empirical Study of Starbucks Coffee in Taiwan. Journal of Social and Development Sciences, 3(1), 24-32.

Urde, A. (2003). Core Value-Based Corporate Brand Building. European Journal of Marketing, 37(7/8). http://dx.doi.org/10.1108/03090560310477645

Valette, F., Guizani, H., \& Merunka, D. (2011). The Impact of Brand Personality and Sales Promotions on Brand Equity. Journal of Business Research, 84(1).

Valls, J., Adrade, M. J., \& Arribas, R. (2011). Consumer Attitudes towards Brands in Times of Great Price Sensitivity. Four Case Studies. Innovative Marketing, 7(2).

Van Auken, B. (2003). Brand Aid: An Easy Reference Guide to Solving Your Toughest Branding Problems and Strengthening Your Market Position. New York: American Management Association.

Walker, D. A. W. (1981). Livestock Development in Nigeria 1914-1979, A Brief Historical Review. Working Document 1. NLPD, Kaduna, Nigeria.

Walshe, M. J., Grindle, J., Nell, A., \& Bachman, M. (1991). Diary Development in Sub-Saharan Africa: A Study of Issues and Options. Africa Technical Department Series, 135. World Bank Technical Paper, Washington DC.

Weber, R. P. (1990). Basic Content Analysis. California: SAGE Publication.

Wheeler, B. M. (2009). The Deep Evolution of Metazoan Micronas. Evolution and Development, 11(1), 50-68. http://dx.doi.org/10.1111/j.1525-142X.2008.00302.x 
Wood, L. (2000). Brands and Brand Equity: Definition and Management. Management Decision, 38(9), 662-669. http://dx.doi.org/10.1108/00251740010379100

Yekinni, A. A. (2013). An Appraisal of the Role of Retail Packaging in Consumer Buying Behaviour: A Case Study of Dairy Powder. International Journal for Management Science and Technology, 5(2), 1-15.

Zenker, S., \& Beckermann, S. C. (2013). My Place is not Your Place-Different Place Brand Knowledge by Different Target Groups. Journal of Place Management and Development, 6(1), 6-17. http://dx.doi.org/10.1108/17538331311306078

\section{Copyrights}

Copyright for this article is retained by the author, with first publication rights granted to the journal.

This is an open-access article distributed under the terms and conditions of the Creative Commons Attribution license (http://creativecommons.org/licenses/by/3.0/) 